Elsevier required licence: (C) <2019>. This manuscript version is made available under the CC-BY-NC-ND 4.0 license http://creativecommons.org/ licenses/by-nc-nd/4.0/. The definitive publisher version is available online at [insert DOI] 
3

4

5

6 8

9

10

11

12

\section{A hybrid forward osmosis/reverse osmosis process for the supply of fertilizing solution from treated wastewater}

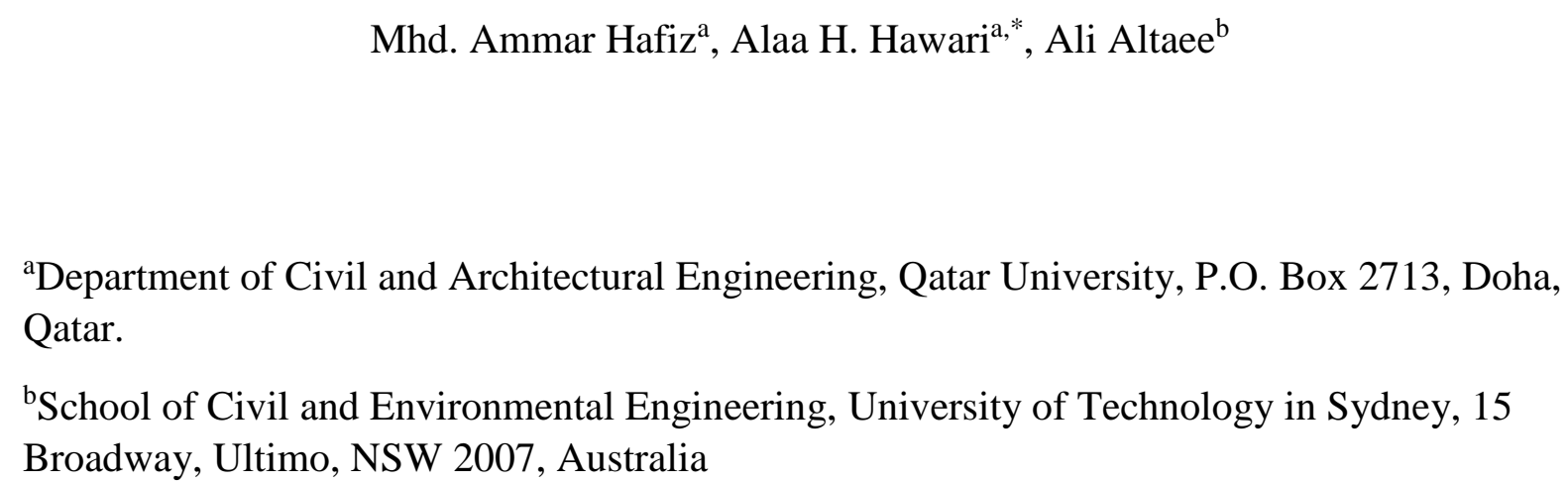

${ }^{a}$ Department of Civil and Architectural Engineering, Qatar University, P.O. Box 2713, Doha, Qatar.

${ }^{\mathrm{b}}$ School of Civil and Environmental Engineering, University of Technology in Sydney, 15

Broadway, Ultimo, NSW 2007, Australia

*Corresponding author: Dr. Alaa H. Hawari, Department of Civil and Architectural Engineering, College of Engineering, Qatar University, 2713 Doha, Qatar.

\section{Email: a.hawari@qu.edu.qa}




\section{Abstract}

This work investigates the application of a hybrid system that combines forward osmosis (FO) and reverse osmosis (RO) processes for the supply of a fertilizing solution that could be used directly for irrigation purposes. In the FO process the feed solution is treated sewage effluent (TSE) and two different types of draw solutions were investigated. The impact of the feed solution and the draw solution flowrates and the membrane orientation on the membrane flux were investigated in the forward osmosis process. $\mathrm{RO}$ was used for the regeneration of the draw solution. In the forward osmosis process it was found that the highest membrane flux was 13.2 LMH. The FO process had high rejection rates for total phosphorus and ammonium which were $99 \%$ and $97 \%$, respectively. RO achieved $99 \%$ total salts rejection rate. Seawater RO (SW30HR) and brackish water RO (BW30LE) membranes were used for the regeneration of the draw solution. The specific power consumption for the regeneration of the draw solution was $2.58 \mathrm{kWh} / \mathrm{m}^{3}$ and $2.18 \mathrm{kWh} / \mathrm{m}^{3}$ for SW30HR and BW30LE membranes, respectively. The final product water had high quality in terms of total dissolved solids concentration but the concentration of phosphorus was slightly higher than recommended due to adding $0.1 \mathrm{M}$ of diammonium phosphate in the draw solution.

Keywords: Forward osmosis; Reverse osmosis; Fertilizing solution; Irrigation water; Membrane flux; Waste water treatment 


\subsection{Introduction}

Water scarcity is one of the most challenging problems that affect agriculture worldwide, especially the arid areas. The United Nations estimates that agriculture accounts for $70 \%$ of the water usage around the world [1]. World population is approximated to be 9 billion by 2050, which will increase demands on the water resources and food resources [2]. Integrated water resources management has become a must practice, of which wastewater reuse is a critical element. Recently, scientists proposed forward osmosis (FO) for the supply of fertilizing solution which will provide the required nutrients to plants [2].

Phuntsho et al. (2013) studied the possibility of producing fertilizing water from brackish groundwater by FO followed by Nanofiltration (NF) [2]. The nanofiltration process was proposed for the regeneration of the draw solution. A maximum water flux of $10 \mathrm{~L} / \mathrm{m}^{2} \cdot \mathrm{h}$ was achieved using brackish groundwater as the feed solution and a $1 \mathrm{M}$ calcium ammonium chloride as the draw solution. For high salinity groundwater, NF process was inefficient to produce a fertilizing solution within the desirable range of nutrients concentration. A further post-treatment was required to reduce the nutrients concentration before the application of the fertilizing solution on crops. Phuntsho et al. (2016) evaluated the performance of pilot scale FDFO-NF to produce irrigation water that meets irrigation standards using coal mining saline groundwater as the draw solution [3]. It was found that FDFO-NF process can produce water that meets irrigation standards. The FO feed brine solution failed to meet discharge standards for ammonium and sulfate due to high reverse solute flux especially at high recovery rate.

Therefore, a FO membrane with lower RSF was recommended to be used for the application of the FDFO process. Using a post-treatment process after the NF process will compromise the cost-effectiveness of the fertilizing solution.

Shaffer et al. (2012) studied the concept of integrated forward osmosis and reverse osmosis process for seawater desalination to produce irrigation water [4]. They found that desalination for irrigation water is an energy-intensive process because of the stringent 
guidelines of nutrients concentration. It was found that the produced solution may also require additional treatment such as a second pass RO. It was shown that an integrated FORO process could achieve boron and chloride water quality for irrigation purposes consuming less energy compared to a two-pass RO process.

Hamdan et al. (2015) compared the behavior of using different binary and ternary solutions as draw solutions in a forward osmosis process [5]. Variable molarity of $\mathrm{MgCl}_{2}$, $\mathrm{NaCl}$, sucrose, and maltose were used as draw solutions to evaluate the performance of forward osmosis. Results showed that the ternary aqueous solution of $\mathrm{MgCl}_{2}$ and $\mathrm{NaCl}$ showed positive synergy and therefore this mixture could be used as a draw solution. Chekli et al. (2017) studied the performance of fertilizer draw forward osmosis (FDFO) using nine different fertilizing draw solution and a synthetic wastewater as the feed solution [6]. It was found that ammonium sulfate (SOA) showed the highest water recovery rate that exceeded $76 \%$, while $\mathrm{KH}_{2} \mathrm{PO}_{4}$ showed the highest water flux recovery that exceeded $75 \%$, and ammonium phosphate monobasic (MAP) showed the lowest final nutrient concentration. Further dilution was still needed to comply with the standards of irrigation water.

Zhao et al. (2011) evaluated the effect of membrane operation mode on FO performance for seawater desalination without foulants and with organic and non-organic foulants [7]. In severe fouling cases, FO mode (active layer towards feed solution) provides higher flux compared to the PRO mode (active layer towards draw solution). Lower possibility of fouling and higher flux recovery was observed while using the FO mode compared to the PRO mode. Hence, FO mode has better performance while using feed solution with higher fouling tendency. Seker et al. (2017) evaluated the effect of membrane orientation on the $\mathrm{FO}$ performance for concentrating Whey with $\mathrm{NH}_{3} / \mathrm{CO}_{2}$ as draw solute [8]. The usage of FO mode provided higher membrane flux of $\left(12 \mathrm{~L} / \mathrm{m}^{2} \mathrm{~h}\right)$ compared to PRO mode membrane flux $\left(6 \mathrm{~L} / \mathrm{m}^{2} \mathrm{~h}\right)$. This is due to high organic and inorganic fouling of Whey 
found on the membrane support surface while using PRO mode. The fertilizer drawn forward osmosis (FDFO) has been studied so far through computational, lab and pilot scale experiments using different feed and draw solution and regeneration processes (i.e. UF and $\mathrm{NF})$.

The objective of this study is to produce a high-quality fertilizing solution that could be directly used for irrigation purposes. This paper evaluates the performance of using an integrated FO-RO process to produce a fertilizing solution applicable for irrigation purposes. In the FO process a real treated sewage effluent (TSE) is used as the feed solution collected from a wastewater treatment plant in Doha. Qatar generates large amounts of low salinity TSE, which cannot be discharged to sea because of the trace concentration of $\mathrm{P}, \mathrm{N}$ and organic matter. The TDS of TSE in Qatar is about $2816 \mathrm{mg} / \mathrm{L}$, which is rather high to be directly used as irrigation water (Table 1). Conventional desalination processes such RO are rather problematic due to the membrane fouling [8] and hence FO membrane was suggested as a pretreatment for the RO process. Two types of draw solutions were studied in the FO system. The first draw solution was made of $0.5 \mathrm{M} \mathrm{NaCl}$ solution, which is used to simulate seawater concentration (TDS $35 \mathrm{~g} / \mathrm{L}$ ) [13]. The second draw solution was composed of $0.5 \mathrm{M}$ $\mathrm{NaCl}$ and $0.01 \mathrm{M}$ diammonium phosphate $\left(\left(\mathrm{NH}_{4}\right)_{2} \mathrm{HPO}_{4}\right)$. The $\mathrm{NaCl}$ was the primary chemical agent of high osmotic pressure and the diammonium phosphate was the chemical agent of nutrients source. Moreover, Seawater RO membrane (SW30HR) and brackish water RO membrane (BW30LE) were tested for the regeneration of the draw solution.

\subsection{Materials and Setup}

\subsection{Forward Osmosis Setup}

A schematic diagram for the FO-RO hybrid system is shown in Figure 1. For the FO system, a Sterlitech CF042 Delrin membrane cell was used. The cell dimensions are 12.7 x 8.3 x 10 $\mathrm{cm}$ with an active inner dimension of $4.6 \times 9.2 \mathrm{~cm}$ and a slot depth of $0.23 \mathrm{~cm}$. The 
membrane was placed inside the cell so that the feed and the draw solutions would flow from each side separately. Two tanks with a capacity of $6 \mathrm{~L}$ were used for the feed and the draw solutions. Two Cole-Parmer gear pumps $(0.91 \mathrm{ml} / \mathrm{rev})$ were used to circulate the feed and the draw solutions through the membrane cell. Two flow meters (Sterlitech Site Read Panel Mount Flow Meter) have been used to measure the flow rate of the feed and the draw solutions. A digital balance (EW-11017-04 Ohaus Ranger ${ }^{\mathrm{TM}}$ Scale) was used to measure the mass change of the DS in order to calculate the water flux in the FO system. The volume of the feed and the draw solutions was $4 \mathrm{~L}$ each at the beginning of each experiment. The solutions going out from the FO cell were recycled back into the same tanks with an operating time of $180 \mathrm{~min}$ for each experiment. A new TFC membrane was used for each trial. A flat sheet TFC FO membrane, FTSH2O (USA), was ordered from Sterlitech Company (USA). The used FO membrane has a high rejection rate for dissolved solids, bacteria and viruses. The membrane was cut to be placed inside the cell with dimensions of $5.75 \times 11.5 \mathrm{~cm}$. The membrane was washed for 20 minutes with distilled water for preconditioning and removal of any chemicals from its surface. A $1 \mathrm{~mm}$ Sepa CF high fouling spacer $(8 \times 3.5 \mathrm{~cm})$ was always placed on the support side of the FO membrane. The membrane was placed into two different modes namely; FO mode (active layer facing the feed solution) and PRO mode (active layer facing the draw solution).

\subsection{Feed and Draw Solution (Forward osmosis)}

The feed solution (FS) in the FO system was treated sewage effluent (TSE). Treated sewage effluent samples were collected after a membrane bioreactor (MBR) unit from Lusail wastewater treatment plant located in Doha, Qatar. The characteristics of the collected TSE samples are summarized in Table 1. The salinity of the TSE was found to be within brackish water range and would require further treatment before being able to use it for irrigation. Two types of draw solutions (DS) were studied in the FO system. The first draw solution was 
made of $0.5 \mathrm{M} \mathrm{NaCl}$ solution (equal to seawater concentration at $35 \mathrm{~g} / \mathrm{L}$ ). The second draw solution was the engineered fertilizing solutions (EFS). The EFS was composed of $0.5 \mathrm{M}$ $\mathrm{NaCl}$ and $0.01 \mathrm{M}$ diammonium phosphate $\left(\left(\mathrm{NH}_{4}\right)_{2} \mathrm{HPO}_{4}\right)$. The diammonium phosphate was added to the draw solution as a nutrient source in the product water while $\mathrm{NaCl}$ is the source of osmotic pressure across the FO membrane. The product water from the hybrid system is supposed to be used directly for irrigation purposes.

Table 1: Characteristics of the treated sewage effluent (TSE) collected form a wastewater treatment plant in Doha, Qatar.

\begin{tabular}{|c|c|c|}
\hline Parameter (unit) & Value & Standard Method \\
\hline $\mathrm{pH}$ & 6.9 & APHA 4500-H+ B. Electrometric Method \\
\hline Temperature (C) & 22.2 & APHA 2550 TEMPERATURE \\
\hline Turbidity (NTU) & 0.84 & APHA 2130 B. Nephelometric Method \\
\hline $\mathrm{COD}(\mathrm{mg} / \mathrm{L})$ & 206.3 & $\begin{array}{l}\text { APHA } 5220 \text { D. Closed Reflux, Colorimetric } \\
\text { Method }\end{array}$ \\
\hline Conductivity $(\mathrm{mS} / \mathrm{cm})$ & 5.12 & APHA 2510 B. Conductivity \\
\hline TDS (mg/L) & 2816 & $\begin{array}{l}\text { APHA } 2540 \mathrm{C} \text {. Total Dissolved Solids Dried } \\
\text { at } 180^{\circ} \mathrm{C}\end{array}$ \\
\hline TSS (g) & 0 & $\begin{array}{l}\text { APHA } 2540 \text { D. Total Suspended Solids } \\
\text { Dried at } 103-105^{\circ} \mathrm{C}\end{array}$ \\
\hline $\mathrm{TP}(\mathrm{mg} / \mathrm{L})$ & 7.583 & $\begin{array}{l}\text { 1. APHA 4500-P C. } \\
\text { Vanadomolybdophosphoric Acid } \\
\text { Colorimetric Method } \\
\text { 2. APHA 4500-P E. Ascorbic Acid Method }\end{array}$ \\
\hline $\mathrm{NH}_{4}(\mathrm{mg} / \mathrm{L})$ & 0.492 & $\begin{array}{l}\text { ASTM D } 1426 \text { - } 03 \text { Standard Test Methods } \\
\text { for Ammonia Nitrogen In Water }\end{array}$ \\
\hline
\end{tabular}

\subsection{Reverse Osmosis Setup}

167 A schematic diagram for the experimental setup is shown in Figure 1. The diluted DS produced from the FO system was used as the feed solution in the reverse osmosis system. 
The reject from the RO system was sent back to the FO system as the regenerated draw solution and the permeate was the produced fertilizing solution. A CF042D crossflow cell assembly, natural acetal copolymer (Delrin) produced by Sterlitech was used for the RO setup. The cell dimensions are $12.7 \times 8.3 \times 10 \mathrm{~cm}$ with active inner dimensions of $4.6 \times 9.2$ $\mathrm{cm}$ and $0.23 \mathrm{~cm}$ slot depth. Two tanks were used to store feed and permeate solutions and a M-03S HYDRACELL pump (230V, 50HZ, 3PH, 6.7 LPM) was used to pressurize the feed solution through the RO membrane. The RO system has a pressure relief valve (1000 PSI/69 bar) in order to ensure a maximum pressure of 69 bar. Concentrate/Back pressure control valve assembly was used to control water flow through the system and to regulate pressure inside the system. Flow meters (Sterlitech Site Read Panel Mount Flow Meter) were used to measure the flow rate at specific points in the RO system. A digital balance (Mettler Toledo ICS 241) was connected to a computer in order to measure the permeate flux in the RO system. Two types of RO membranes were used, SW30HR and BW30LE membranes produced by DOW Company. Both membranes have a high rejection rate, which can reach up to $99.6 \%$ and flux of $29-41 \mathrm{LMH}$. The SW30HR membrane is used for the treatment of seawater with a pore size of $100 \mathrm{Da}$. The BW30LE membrane is used for brackish water treatment with a flux of $44 \mathrm{LMH}$ and rejection rate of $99 \%$ and pore size of $100 \mathrm{Da}$. Both membranes were washed for 30 minutes with distilled water before use for pre-conditioning and removal of any impurities from their surface. 


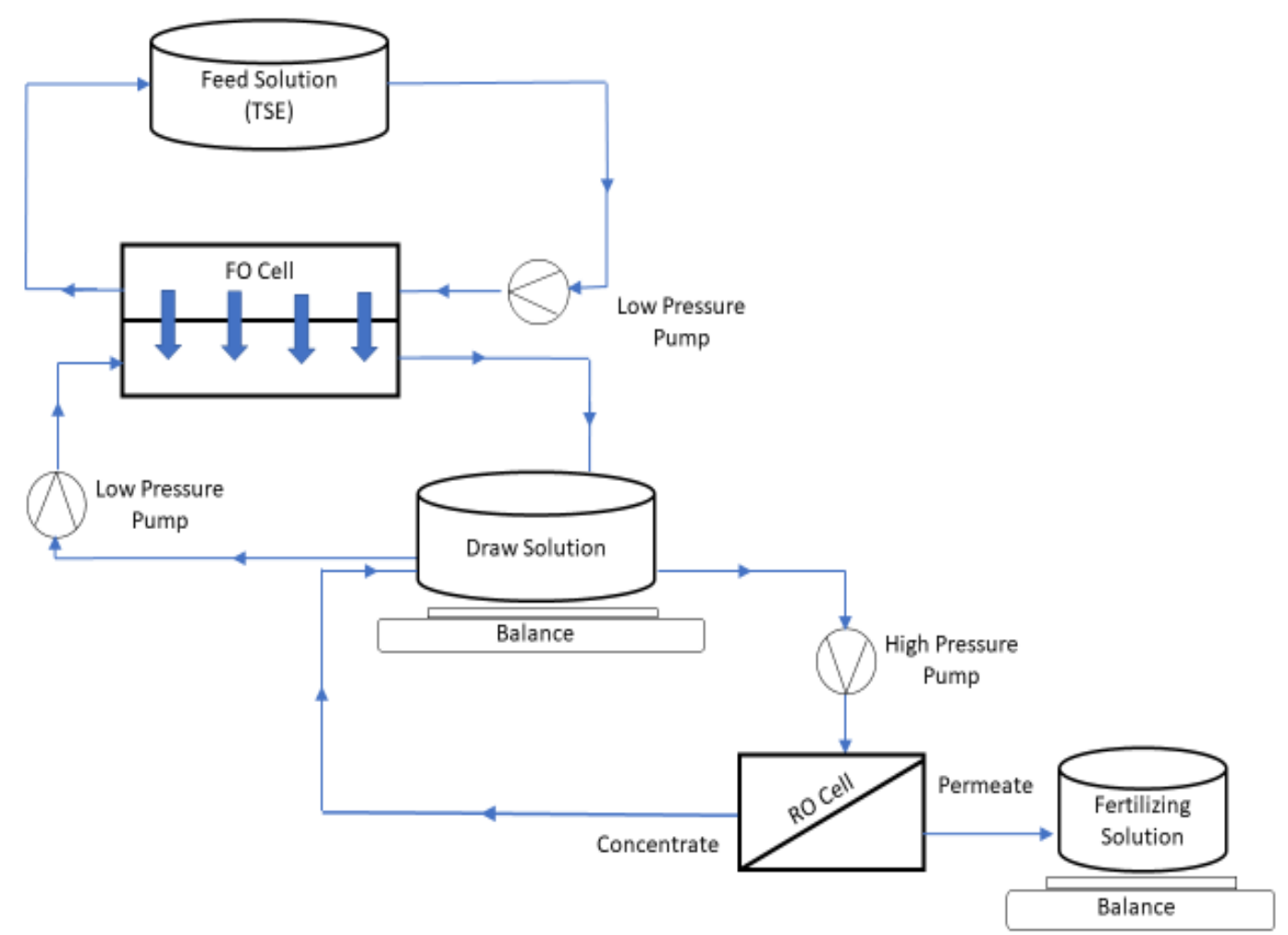

Figure 1: The hybrid FO-RO system used for the production of the engineered fertilizing solution.

Finally, a simulation software produced by DOW Co. named ROSA was used to calculate the energy consumed by the RO process using the two different membranes. A

193 single unit with eight vessels was used in the model. The specific energy consumption (Es) is calculated using the following expression[9]:

$$
E s=\frac{P * Q_{f}}{n \cdot * Q_{p}}
$$

Where, $P$ is the hydraulic pressure (bar), $Q_{f}$ is the flow rate of feed solution $(\mathrm{L} / \mathrm{h}), n$ is the pump efficiency $(0.8)$, and $Q_{p}$ is the permeate flow rate $(\mathrm{L} / \mathrm{h})$. The applied pressure was 50 and 40 bar for SW30HR and BW30LE, respectively. The water quality and concentration of multiple ions were specified. 


\subsection{Results and Discussion}

$201 \quad 3.1$ Forward osmosis

202 3.1.1 Membrane flux

203 The study investigated the impact of the flow rates of the DS and the FS and the membrane

204 orientation on the membrane flux. It can be seen from Figure 2 (A) and (B) that when the two

205 different draw solutions were used, the membrane flux decreased with time in both

206 membrane orientations. The decrease of the membrane flux was due to the dilution of the

207 draw solution and FO membrane fouling. Moreover, TSE contains trace concentration of

208 organic matters, which are source of contamination and FO membrane fouling when

209 accumulate on the membrane surface [7, 10-12].

210

211

212

213 

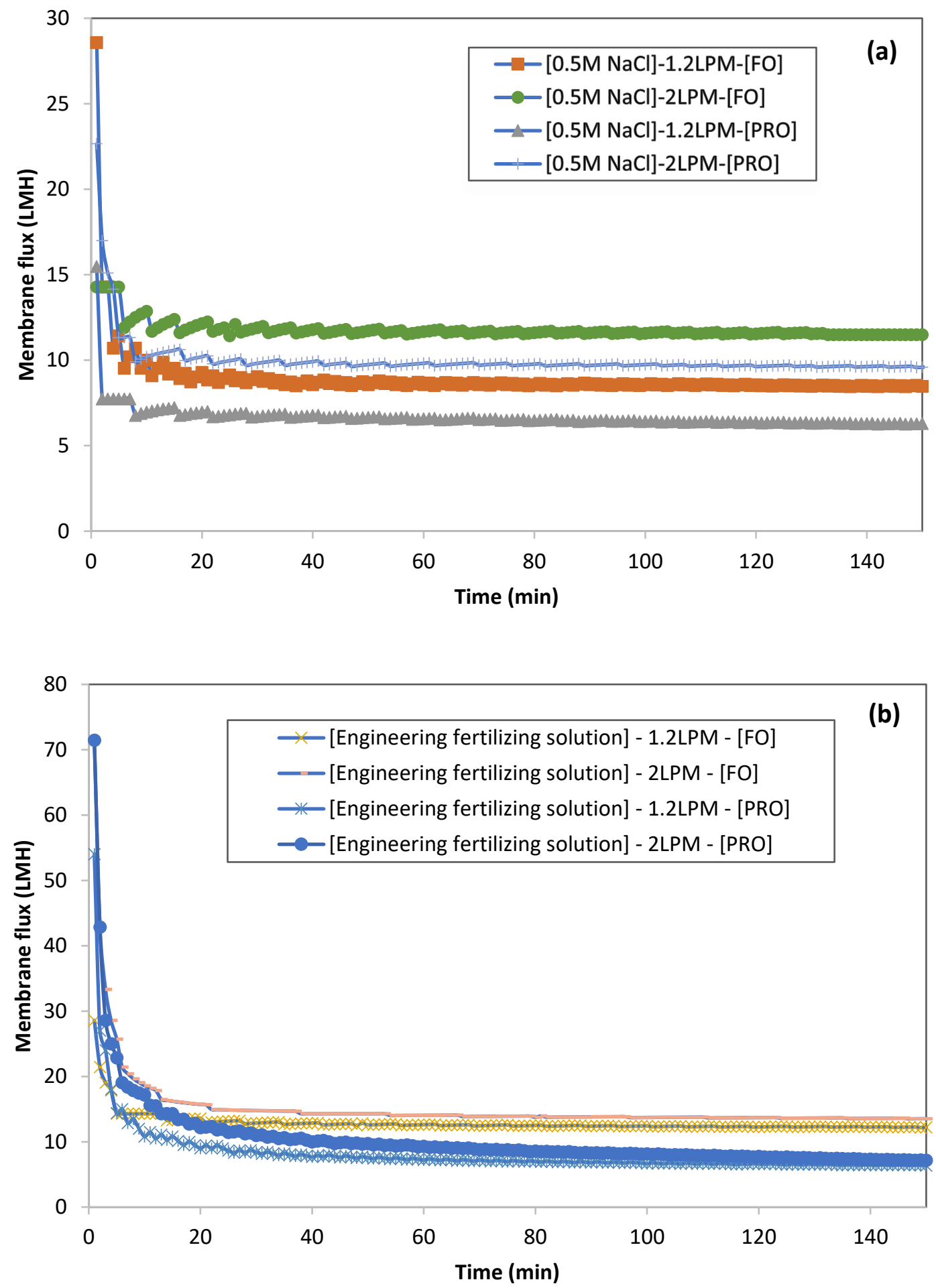

216 Figure 2: Membrane flux using different draw solutions in FO mode and PRO mode at

217 different DS and FS flow rates (a) $0.5 \mathrm{M} \mathrm{NaCl}$ draw solution (b) EFS draw solution.

It can be seen from Figure 3 that the average membrane flux increased as the flow rates of the draw solution and the feed solution increased in both membrane orientations. In 
FO mode, when $0.5 \mathrm{M} \mathrm{NaCl}$ was used as the draw solution, the average membrane flux increased from $9.0 \mathrm{~L} / \mathrm{m}^{2} . \mathrm{h}$ to $11.8 \mathrm{~L} / \mathrm{m}^{2} . \mathrm{h}$ as the flow rates of the draw and the feed solutions increased from $1.2 \mathrm{~L} / \mathrm{min}$ to $2 \mathrm{~L} / \mathrm{min}$, respectively. In the PRO mode the average membrane flux increased from $5.5 \mathrm{~L} / \mathrm{m}^{2} . \mathrm{h}$ to $10.0 \mathrm{~L} / \mathrm{m}^{2} . \mathrm{h}$ as the flow rates of the draw and the feed solutions increased from 1.2 to L/min $2 \mathrm{~L} / \mathrm{min}$, respectively. As shown in Figure 3 a similar trend was observed for the EFS where in the FO mode the average membrane flux increased from $11.0 \mathrm{~L} / \mathrm{m}^{2} . \mathrm{h}$ to $13.2 \mathrm{~L} / \mathrm{m}^{2} . \mathrm{h}$ as the flow rates of the draw and the feed solutions increased from $1.2 \mathrm{~L} / \mathrm{min}$ to $2 \mathrm{~L} / \mathrm{min}$, respectively. In the PRO mode the average membrane flux increased from $8.0 \mathrm{~L} / \mathrm{m}^{2} . h$ to $10.5 \mathrm{~L} / \mathrm{m}^{2} . \mathrm{h}$ as the flow rates of the draw and the feed solutions increased from $1.2 \mathrm{~L} / \mathrm{min}$ to $2 \mathrm{~L} / \mathrm{min}$, respectively. The increase of the membrane flux with the increase of the flow rates of the draw and the feed solutions is due to the minimized concentration polarization effect at higher flow rates [13]. Concentration polarization plays a major role in decreasing the osmotic effect across the FO membrane which would decrease the membrane flux $[14,15]$. Increasing the flow rates of the draw and the feed solutions would increase the turbulence around the membrane surface, which in turn reduces the effect of concentration polarization and increases the mass transfer coefficient [16]. Moreover, Figure 3 shows that using EFS as the draw solution resulted in a higher average membrane flux compared to when using $0.5 \mathrm{M} \mathrm{NaCl}$ as the draw solution. This is due to the fact that the osmotic pressure of $\left(\mathrm{NH}_{4}\right)_{2} \mathrm{HPO}_{4}$ is 50 atm and the osmotic pressure of $\mathrm{NaCl}$ is 39 atm for the same concentration. The osmotic pressure of $0.5 \mathrm{M} \mathrm{NaCl}$ and $0.01 \mathrm{M}$ diammonium phosphate (DAP) mixture (i.e. EFS) is higher than that of $0.5 \mathrm{M} \mathrm{NaCl}$. Therefore, it is expected that the driving force of the EFS draw solution would be higher than that of the $0.5 \mathrm{M} \mathrm{NaCl}$ draw solution. Figure 3 also shows that the average membrane flux in the FO mode was always higher than that in the PRO mode for both the $0.5 \mathrm{M} \mathrm{NaCl}$ and $\mathrm{EFS}$ draw solutions. In the PRO mode, the support layer faces the feed solution, which in this case was the TSE. Using 
such a feed solution with a high concentration of organic matter could promote membrane

246 fouling due to the accumulation of foulants on the rough support layer [17]. The rough

247 surface of the support layer would provide more surface area for the foulants to reside on

248 [18]. The SEM images show that high concentration of foulants accumulated on the surface

249 of the support layer when it is facing the TSE feed solution (PRO mode) compared to when the support layer was facing the EFS (i.e. FO mode) (Figure 4). Similar findings were reported in the literature where the FO mode resulted in a higher membrane flux compared to the PRO mode [7, 19]. In general, the FO mode is recommended when the feed solution contains high concentration of fouling materials such as TSE. While the PRO mode is recommended when using a feed solution with low concentration of fouling materials [7].

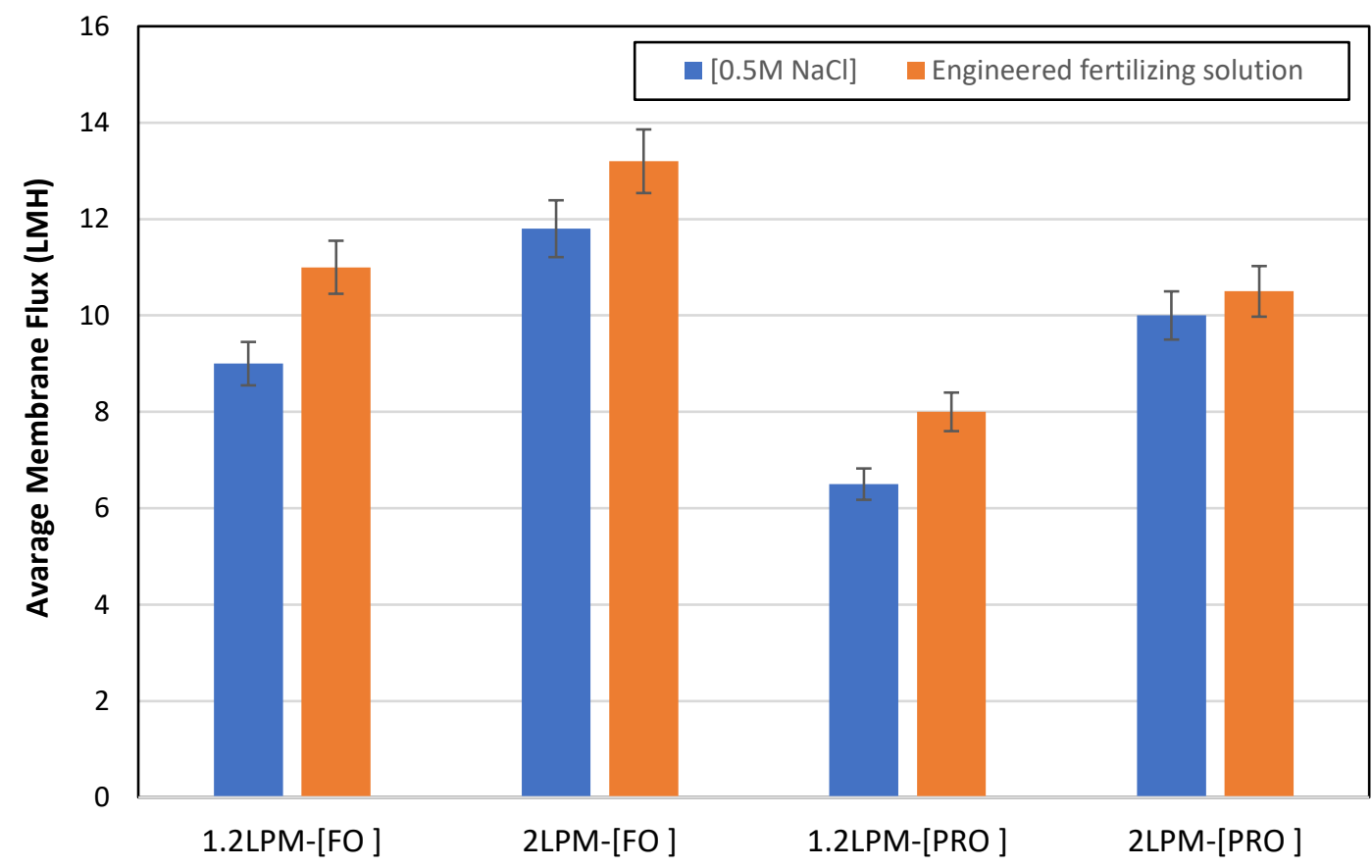

Figure 3: Average membrane flux using different draw solutions in FO mode and PRO mode at different DS and FS flow rates. 

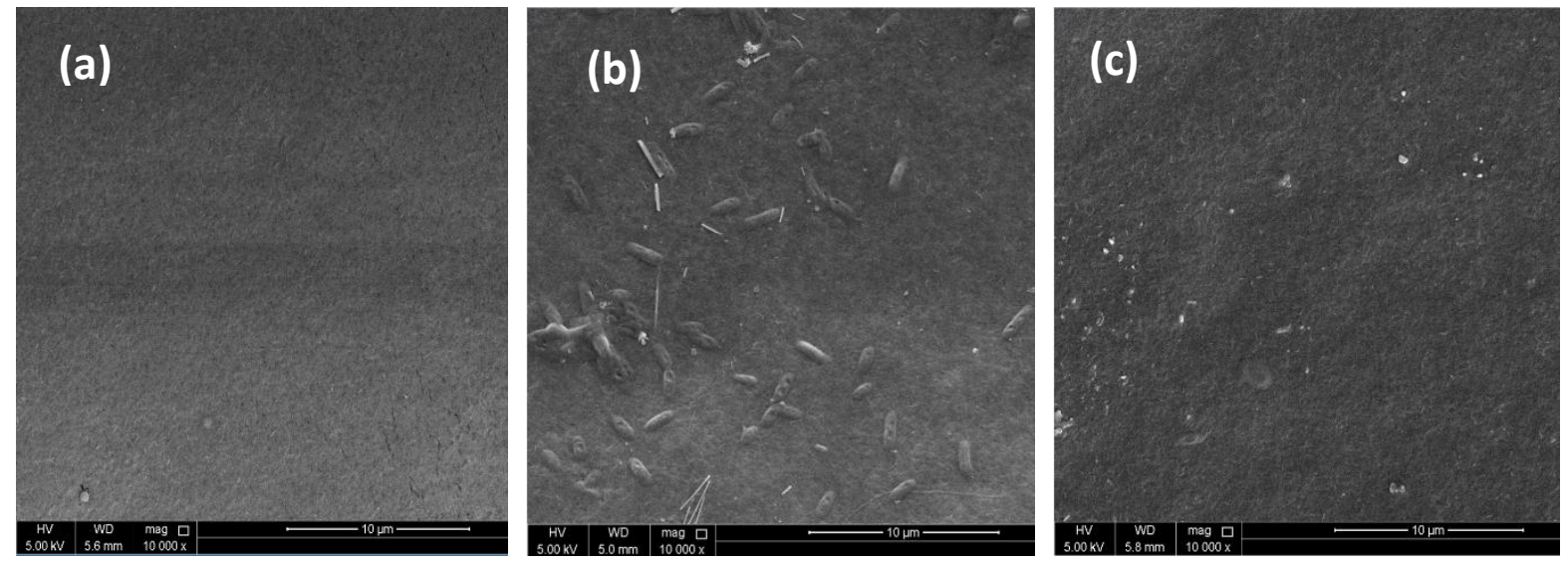

Figure 4: SEM images of the FO membrane at FS and DS flow rates of 1.2LPM, using EFS

as draw solution and TSE as the feed solution (a) Clean Support layer, (b) Support layer

facing the feed solution (PRO mode), (c) Support Layer facing the draw solution (FO mode).

\subsubsection{Reverse solute flux (RSF)}

Reverse solute flux (RSF) is the back diffusion of the draw solute across the FO membrane to the feed solution. RSF must be considered in the FO studies because it might contaminate the feed solution. Figure 5 shows that the RSF decreased as the flow rates of the feed and draw solutions increased for $0.5 \mathrm{M} \mathrm{NaCl}$ and EFS draw solutions in both membrane orientations. In the FO mode and when EFS was used as the draw solution the RSF was $74.3 \mathrm{~g} / \mathrm{m}^{2} . \mathrm{h}$ and 70.3 $\mathrm{g} / \mathrm{m}^{2} . \mathrm{h}$ at 1.2 LPM and 2.0 LPM flow rates of the draw and the feed solutions, respectively. When $0.5 \mathrm{M} \mathrm{NaCl}$ solution was used as the draw solution, the RSF was $48.3 \mathrm{~g} / \mathrm{m}^{2} . \mathrm{h}$ and 44.9 $\mathrm{g} / \mathrm{m}^{2} . \mathrm{h}$ at 1.2 LPM and 2.0 LPM flow rates of the draw and the feed solutions, respectively. In the PRO mode, when EFS was used as the draw solution the RSF was $66.7 \mathrm{~g} / \mathrm{m}^{2} . \mathrm{h}$ and 65.1 $\mathrm{g} / \mathrm{m}^{2} . \mathrm{h}$ at 1.2 LPM and 2.0 LPM flow rates of the draw and the feed solutions, respectively. When $0.5 \mathrm{M} \mathrm{NaCl}$ solution was used as the draw solution, the RSF was $43.7 \mathrm{~g} / \mathrm{m}^{2} . \mathrm{h}$ and 38.6 $\mathrm{g} / \mathrm{m}^{2} . \mathrm{h}$ at 1.2 LPM and 2.0 LPM flow rates of the draw and the feed solution, respectively. 
$\mathrm{NaCl}$ solution was used as the draw solution. $\mathrm{NaCl}$ has high $\mathrm{RSF}$ due to its small ion size [2022]. The addition of $0.01 \mathrm{M}$ of diammonium phosphate (DAP) in the draw solution has lowered the RSF by an average of $36 \%$ in all operating conditions because DAP is a large molecule with a high molecular weight and high chelating ability [22]. In addition, $\left(\mathrm{NH}_{4}\right)_{2} \mathrm{HPO}_{4}$ is a weak alkaline. At this working $\mathrm{pH}$, FO membrane remains slightly negatively charged. This negative charge could repel phosphate containing anions, which are usually made up of higher hydrated diameter with greater force. Previous studies also reported lower RSF for draw solutions containing $\mathrm{SO}_{4}^{-2}$ and $\mathrm{Ca}^{+2}$ species [11].

289

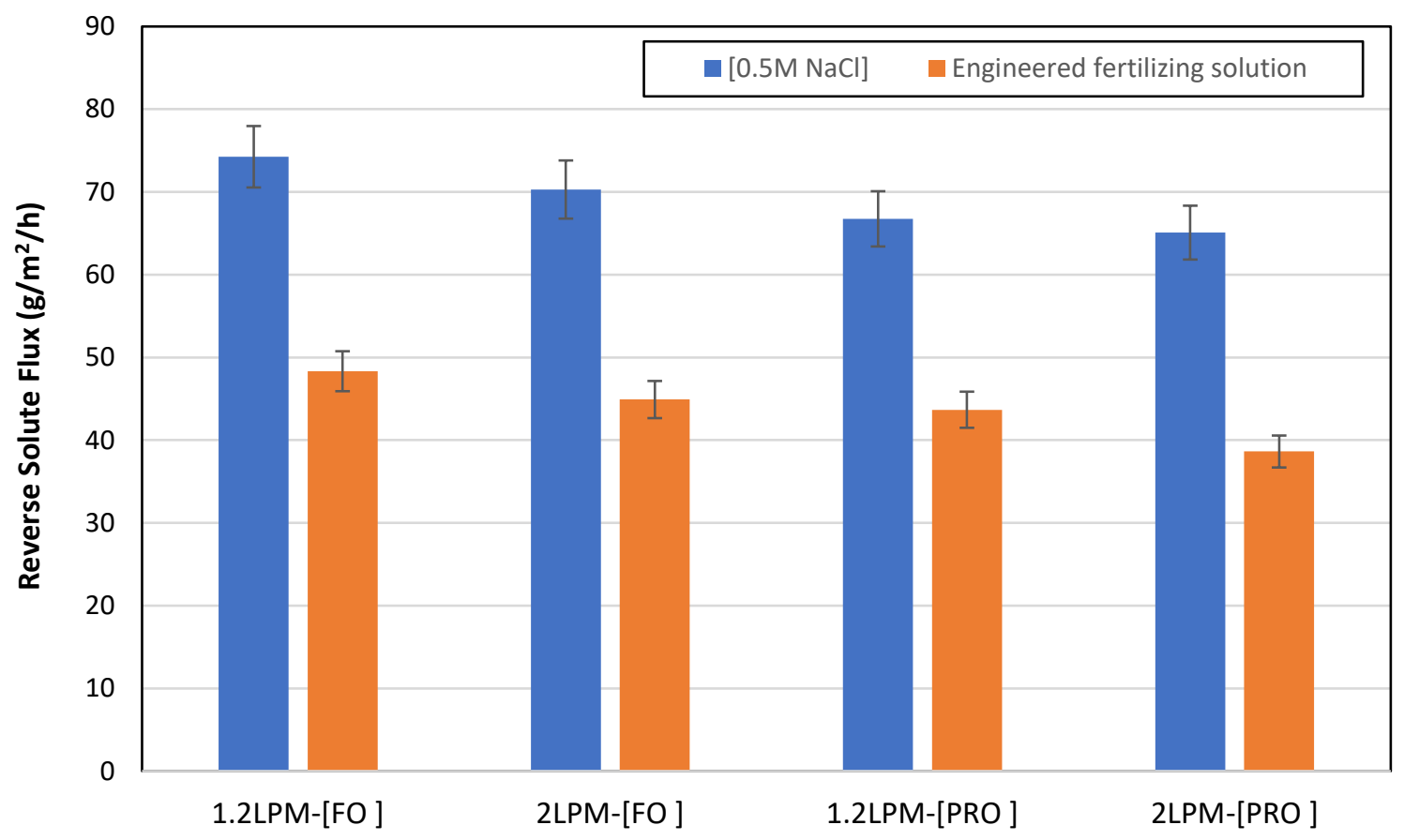

Figure 5: RSF in the FO using TSE as a feed solution and $0.5 \mathrm{M} \mathrm{NaCl}$ or Engineered fertilizing solution as draw solution

\subsubsection{Rejection rate}

Rejection rate indicate the amount of nutrient present in the solution after the FO process. It was found that the used FO membrane had high rejection for total phosphorous (TP) and ammonium $\left(\mathrm{NH}_{4}^{+}\right)$as shown in Figure 6. It can be seen from Figure 6 (A) that the total phosphorus (TP) rejection rate exceeded $99 \%$ in the FO mode and in the PRO mode at 1.2 
LPM and 2 LPM flowrates of DS and FS. Phosphorous rejection rate is high due to its high molecular weight and large hydrated ion diameter [14]. It can be seen from Figure 6 (B) that ammonium $\left(\mathrm{NH}_{4}^{+}\right)$rejection rate was lower than the TP rejection rate. Where in the PRO

301 mode the ammonium rejection rate was $92.5 \%$ and $95 \%$ at 1.2 LPM and 2 LPM DS and FS

302 flowrates, respectively. In the FO mode the ammonium rejection rate was $95 \%$ and $97 \%$ at

303 1.2 LPM and 2 LPM DS and FS flowrates, respectively. The $\mathrm{NH}_{4}{ }^{+}$rejection rate is lower than

304 the total phosphorus rejection rate because of ammonium's lower molecular weight and

305 smaller hydrated ion diameter [14]. It can also be noticed that ammonium rejection rate was

306 generally higher in the PRO mode compared to the FO mode due to the fact that the used

307 TFC FO membrane attracts positively charged ions (i.e. $\mathrm{NH}^{4+}$ )[23]. 

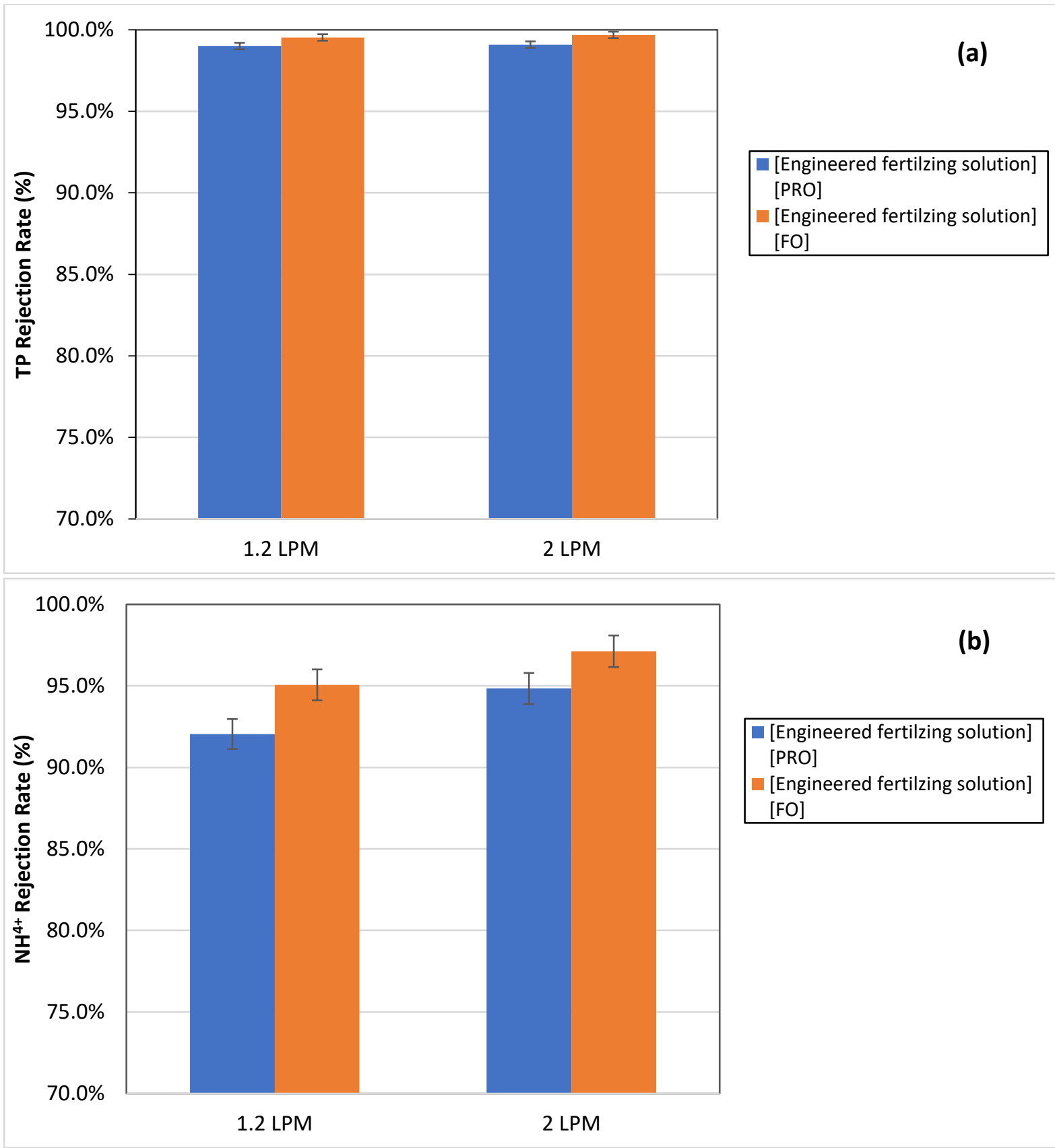

311 Figure 6: Rejection rate at different DS and FS flow rates and different membrane orientations with TSE as feed solution and Engineered fertilizing solution as draw solution (a) Total phosphorus (TP) rejection rate (b) Ammonium $\left(\mathrm{NH}^{4+}\right)$ rejection rate.

\subsection{Regeneration of draw solution using reverse osmosis process}

315 The objective of using Reverse osmosis (RO) was to regenerate the diluted draw solution

316 (DS). A single stage reverse osmosis membrane separation process was used in this study.

317 According to the membrane manufacturer (DOW), a total salt rejection rate of $99.7 \%$ can be 
achieved by SW30HR DOW membrane and $99.0 \%$ by BW30LE DOW membrane. The calculated total salts rejection rate was found to be $99 \%$ and $98 \%$ for SW30HR DOW and BW30LE DOW, respectively. Table 2 summarizes the conductivity of the feed and permeate solutions in the RO system using the two different RO membranes. The permeate conductivity was $0.410 \mathrm{mS} / \mathrm{cm}$ and $0.767 \mathrm{mS} / \mathrm{cm}$ for SW30HR and BW30LE membrane, respectively which were within the range specified by the Food and Agriculture Orgnization of the United Nation for irrigation water [24]. The concentration of other ions in the permeate solution were furtherly checked in order to ensure that the product fertilizing solution contains the right concentrations. According to the Food and agriculture organization of the united nations (FAO), the max concentration of sulfate in irrigation water is $321 \mathrm{mg} / \mathrm{l}$. Table 2 shows that the sulfate concentration in the product fertilizing solution was $2.5 \mathrm{mg} / \mathrm{l}$ and $22.0 \mathrm{mg} / \mathrm{l}$ using SW30HR and BW30LE membranes, respectively which were below the required sulfate concentration specified by Food and agriculture organization of the united nations (FAO) for irrigation water [24]. According to the Food and agriculture organization of the united nations (FAO), the max concentration of chloride in irrigation water is $350 \mathrm{mg} / \mathrm{l}$ taking into consideration that sensitive crops may show some injuries with a concentration above $140 \mathrm{mg} / \mathrm{l}$. The chloride concentration in the product fertilizing solution was $117.9 \mathrm{mg} / \mathrm{l}$ and $176.7 \mathrm{mg} / \mathrm{l}$ using SW30HR and BW30LE membranes, respectively. According to FAO the maximum concentration of sodium in irrigation water is $46-230 \mathrm{mg} / \mathrm{l}$. A Sodium concentration of $170.2 \mathrm{mg} / \mathrm{l}$ and $246.4 \mathrm{mg} / \mathrm{l}$ was obtained in the product water using SW30HR and BW30LE membranes, respectively. As seen in Table 2, the concentration of chloride, nitrate, sulfate, sodium and conductivity of the generated fertilizing solution was within the required range specified by the Food and Agriculture Orgnization of the United Nation for irrigation water [24]. However, the concentration of phosphate concentration is above the range specified by FAO. According to FAO the maximum concentration of 
phosphate in irrigation water is $2 \mathrm{mg} / \mathrm{l}$. The Phosphate concentration in the product fertilizing solution was $6.6 \mathrm{mg} / \mathrm{l}$ and $27.8 \mathrm{mg} / \mathrm{l}$ using SW30HR and BW30LE membranes, respectively. The phosphate concentration in the product water using SW30HR was $75 \%$ lower than BW30LE. Regenerating the EFS with SW30HR membrane yielded a better quality fertilizing solution in terms compliance with the FAO guidelines for irrigation water (Table 2).

Therefore, SW30HR membrane is recommended for the regeneration of EFS in this study.

The phosphate concentration in the product water did not comply with FAO. The concentration of phosphate was still almost 3 times higher than what is recommended by FAO. A RO system with two passes could resolve this issue or a lower concentration of DAP in the draw solution could also lower the phosphate concentration in the product water.

As shown in Table 2 the energy consumption in the RO process for the SW30HR and BW30LE membranes were $2.58 \mathrm{Kwh} / \mathrm{m}^{3}$ and $2.18 \mathrm{Kwh} / \mathrm{m}^{3}$, respectively. The specific power consumption for TSE treatment is slightly higher than reported in previous literature using membrane bioreactor (MBR)-RO and was between 1.2 and $1.5 \mathrm{kWh} / \mathrm{m}^{3}$ [24]. Scaling up the experimental work from laboratory to field would, probably, reduce the specific power consumption for TSE treatment. The other advantage of using FO pretreatment is to reduce the fouling problems in the RO process that can be avoided by the MBR process. Therefore, it would be highly recommended to use SW30HR membrane in the RO system since it had lower energy consumption and better quality of product water especially for phosphate where the concentration of phosphate was $77 \%$ lower than the phosphate concentration in the permeate solution when using the BW30LE membrane.

Table 2: Permeate solution characteristics after the RO treatment.

\begin{tabular}{lccc}
\hline & $\begin{array}{c}\text { Permeate SW30HR } \\
\text { DOW }\end{array}$ & Permeate BW30LE & $\begin{array}{c}\text { Max Limit } \\
\text { (Irrigation water) } \\
\text { [24] }\end{array}$ \\
\hline Chloride (ppm) & 117.9 & 176.7 & 350 \\
\hline
\end{tabular}




\begin{tabular}{lccc}
\hline Nitrate (ppm) & 0.230 & 0.280 & 5 \\
\hline Phosphate (ppm) & 6.6 & 27.8 & 2 \\
\hline Sulfate (ppm) & 2.5 & 22.0 & 321 \\
\hline Sodium (ppm) & 170.3 & 246.5 & 230 \\
\hline $\begin{array}{l}\text { Feed solution } \\
\text { conductivity (mS/cm) }\end{array}$ & 33.4 & 33.4 & - \\
\hline $\begin{array}{l}\text { Permeate solution } \\
\text { conductivity(mS/cm) }\end{array}$ & 0.410 & 0.767 & 0.75 \\
\hline $\begin{array}{l}\text { Energy consumption } \\
\left(\mathbf{k W h} / \mathbf{m}^{\mathbf{3}} \text { ) }\right.\end{array}$ & 2.58 & 2.18 & - \\
\hline $\begin{array}{l}\text { Initial Feed solution } \\
\text { conductivity (mS/cm) }\end{array}$ & 33.4 & 33.4 & - \\
\hline
\end{tabular}

\subsection{Conclusions}

367 This paper evaluated the performance of an integrated FO-RO process to produce a fertilizing solution applicable for irrigation purposes. In the FO process real treated sewage effluent (TSE) was used as the feed solution and two types of draw solutions were tested namely, $0.5 \mathrm{M} \mathrm{NaCl}$ solution and a mixture of $0.5 \mathrm{M} \mathrm{NaCl}$ and $0.01 \mathrm{M}$ Diammonium phosphate $\left(\left(\mathrm{NH}_{4}\right)_{2} \mathrm{HPO}_{4}\right)$. Seawater RO membrane (SW30HR) and brackish water RO membrane (BW30LE) were tested for the regeneration process of the draw solution. In the FO process the impact of the flow rate of the feed solution and the draw solution, the membrane orientation (i.e. FO mode and PRO mode) on the membrane flux were tested. The following conclusions were drawn:

- Using a mixture of $0.5 \mathrm{M} \mathrm{NaCl}$ and $0.01 \mathrm{M}$ Diammonium phosphate $\left(\left(\mathrm{NH}_{4}\right)_{2} \mathrm{HPO}_{4}\right)$ as the draw solution resulted in a higher average membrane flux compared to when using $0.5 \mathrm{M} \mathrm{NaCl}$ alone as the draw solution. This is due to the fact that the osmotic pressure of $0.5 \mathrm{M} \mathrm{NaCl}$ and $0.01 \mathrm{M}$ diammonium phosphate (DAP) mixture is higher 
than that of $0.5 \mathrm{M} \mathrm{NaCl}$ alone. Therefore, it is expected that the driving force of the mixed draw solution would be higher than that of the $0.5 \mathrm{M} \mathrm{NaCl}$ draw solution.

- The average membrane flux in the FO mode was always higher than that in the PRO mode for both the $0.5 \mathrm{M} \mathrm{NaCl}$ solution and the $0.5 \mathrm{M} \mathrm{NaCl}$ and $0.01 \mathrm{M}$ diammonium phosphate mixture. In the PRO mode, the support layer faces the feed solution, which in this case was the TSE. Using such a feed solution with a high concentration of organic matter could promote membrane fouling due to the accumulation of foulants on the rough support layer. It is recommended that the FO mode should be used when the feed solution contains high concentration of fouling materials. While the PRO mode is recommended when using a feed solution with low concentrations of fouling materials.

- The addition of $0.01 \mathrm{M}$ of diammonium phosphate (DAP) in the draw solution has lowered the RSF by an average of $36 \%$ in all operating conditions. DAP is a large molecule with a high molecular weight and high chelating ability which could be the reason behind the high reduction in the RSF.

- It was found that the used FO membrane had high rejection rate for total phosphorous (TP) and ammonium $\left(\mathrm{NH}^{4+}\right)$. The total phosphorus (TP) rejection rate exceeded $99 \%$ in the FO mode and in the PRO mode at 1.2 LPM and 2 LPM flowrates of DS and FS. The ammonium $\left(\mathrm{NH}^{4+}\right)$ rejection rate was lower than the TP rejection rate. Where in the PRO mode the ammonium rejection rate was $92.5 \%$ and $95 \%$ at $1.2 \mathrm{LPM}$ and 2 LPM DS and FS flowrates, respectively. In the FO mode the ammonium rejection rate was $95 \%$ and $97 \%$ at 1.2 LPM and 2 LPM DS and FS flowrates, respectively. The $\mathrm{NH}^{4+}$ rejection rate is lower than the total phosphorus rejection rate because of ammonium lower molecular weight and smaller hydrated ion diameter. 
- It would be highly recommended to use SW30HR membrane in the RO system for the regeneration of the draw solution since this membrane had lower energy consumption and better quality of product water especially for phosphate where the concentration of phosphate was $77 \%$ lower than the phosphate concentration in the permeate solution when using the BW30LE membrane.

\section{Acknowledgments}

This project is supported by Qatar National Research Fund (QNRF) under Qatar Research

Leadership Program - Graduate Sponsorship Research award “GSRA4-2-0402-17013”. The

authors also wish to thank Qatar Works Authority (Ashghal) for the supply of the treated

wastewater.

\section{References}

[1] UnitedNations. "Water." http://www.un.org/en/sections/issues-depth/water/ (accessed 29/01/2018, 2018).

[2] S. Phuntsho, S. Hong, M. Elimelech, and H. K. Shon, "Forward osmosis desalination of brackish groundwater: Meeting water quality requirements for fertigation by integrating nanofiltration," Journal of Membrane Science, vol. 436, pp. 1-15, 2013/06/01/ 2013, doi: https://doi.org/10.1016/j.memsci.2013.02.022.

[3] S. Phuntsho et al., "Fertiliser drawn forward osmosis process: Pilot-scale desalination of mine impaired water for fertigation," Journal of Membrane Science, vol. 508, pp. 22-31, 2016/06/15/ 2016, doi: https://doi.org/10.1016/i.memsci.2016.02.024.

[4] D. L. Shaffer, N. Y. Yip, J. Gilron, and M. Elimelech, "Seawater desalination for agriculture by integrated forward and reverse osmosis: Improved product water quality for potentially less energy," Journal of Membrane Science, vol. 415-416, pp. 1-8, 2012/10/01/ 2012, doi: https://doi.org/10.1016/i.memsci.2012.05.016.

[5] M. Hamdan, A. O. Sharif, G. Derwish, S. Al-Aibi, and A. Altaee, "Draw solutions for Forward Osmosis process: Osmotic pressure of binary and ternary aqueous solutions of magnesium chloride, sodium chloride, sucrose and maltose," Journal of Food Engineering, vol. 155, pp. 1015, 2015/06/01/ 2015, doi: https://doi.org/10.1016/i.jfoodeng.2015.01.010.

[6] L. Chekli et al., "Evaluation of fertilizer-drawn forward osmosis for sustainable agriculture and water reuse in arid regions," Journal of Environmental Management, vol. 187, pp. 137-145, 2017/02/01/ 2017, doi: https://doi.org/10.1016/j.jenvman.2016.11.021.

[7] S. Zhao, L. Zou, and D. Mulcahy, "Effects of membrane orientation on process performance in forward osmosis applications," Journal of Membrane Science, vol. 382, no. 1, pp. 308-315, 2011/10/15/ 2011, doi: https://doi.org/10.1016/j.memsci.2011.08.020.

[8] M. Seker et al., "Effect of pretreatment and membrane orientation on fluxes for concentration of whey with high foulants by using NH3/CO2 in forward osmosis," Bioresource Technology, vol. 243, pp. 237-246, 2017/11/01/ 2017, doi: https://doi.org/10.1016/i.biortech.2017.06.101. 
[9] A. Altaee, G. J. Millar, A. O. Sharif, and G. Zaragoza, "Forward osmosis process for supply of fertilizer solutions from seawater using a mixture of draw solutions," Desalination and Water Treatment, vol. 57, no. 58, pp. 28025-28041, 2016/12/13 2016, doi: 10.1080/19443994.2016.1180642.

[10] J. C. Ortega-Bravo, G. Ruiz-Filippi, A. Donoso-Bravo, I. E. Reyes-Caniupán, and D. Jeison, "Forward osmosis: Evaluation thin-film-composite membrane for municipal sewage concentration," Chemical Engineering Journal, vol. 306, pp. 531-537, 2016/12/15/ 2016, doi: https://doi.org/10.1016/j.cej.2016.07.085.

[11] A. J. Ansari, F. I. Hai, W. Guo, H. H. Ngo, W. E. Price, and L. D. Nghiem, "Factors governing the pre-concentration of wastewater using forward osmosis for subsequent resource recovery," Science of The Total Environment, vol. 566-567, pp. 559-566, 2016/10/01/ 2016, doi: https://doi.org/10.1016/i.scitotenv.2016.05.139.

[12] R. Valladares Linares, Z. Li, M. Abu-Ghdaib, C.-H. Wei, G. Amy, and J. S. Vrouwenvelder, "Water harvesting from municipal wastewater via osmotic gradient: An evaluation of process performance," Journal of Membrane Science, vol. 447, pp. 50-56, 2013/11/15/ 2013, doi: https://doi.org/10.1016/j.memsci.2013.07.018.

[13] J. R. McCutcheon and M. Elimelech, "Influence of concentrative and dilutive internal concentration polarization on flux behavior in forward osmosis," Journal of Membrane Science, vol. 284, no. 1, pp. 237-247, 2006/11/01/ 2006, doi: https://doi.org/10.1016/i.memsci.2006.07.049.

[14] Y. P. Devia, T. Imai, T. higuchi, A. Kanno, K. Yamamoto, and M. Sekine, "Effect of Operating Conditions on Forward Osmosis for Nutrient Rejection Using Magnesium Chloride as a Draw Solution," in International Journal of Environmental, Chemical, Ecological, Geological and Geophysical Engineering, 2015, vol. 9, pp. 690-696.

[15] A. H. Hawari, A. Al-Qahoumi, A. Ltaief, S. Zaidi, and A. Altaee, "Dilution of seawater using dewatered construction water in a hybrid forward osmosis system," Journal of Cleaner Production, vol. 195, pp. 365-373, 2018/09/10/ 2018, doi: https://doi.org/10.1016/i.jclepro.2018.05.211.

[16] D. H. Jung et al., "Simulation of forward osmosis membrane process: Effect of membrane orientation and flow direction of feed and draw solutions," Desalination, vol. 277, no. 1, pp. 83-91, 2011/08/15/ 2011, doi: https://doi.org/10.1016/i.desal.2011.04.001.

[17] V. Parida and H. Y. Ng, "Forward osmosis organic fouling: Effects of organic loading, calcium and membrane orientation," Desalination, vol. 312, pp. 88-98, 2013/03/01/ 2013, doi: https://doi.org/10.1016/i.desal.2012.04.029.

[18] R. Honda, W. Rukapan, H. Komura, Y. Teraoka, M. Noguchi, and E. M. V. Hoek, "Effects of membrane orientation on fouling characteristics of forward osmosis membrane in concentration of microalgae culture," Bioresource Technology, vol. 197, pp. 429-433, 2015/12/01/ 2015, doi: https://doi.org/10.1016/i.biortech.2015.08.096.

[19] C. Y. Tang, Q. She, W. C. L. Lay, R. Wang, and A. G. Fane, "Coupled effects of internal concentration polarization and fouling on flux behavior of forward osmosis membranes during humic acid filtration," Journal of Membrane Science, vol. 354, no. 1, pp. 123-133, 2010/05/15/ 2010, doi: https://doi.org/10.1016/i.memsci.2010.02.059.

[20] N. T. Hancock and T. Y. Cath, "Solute Coupled Diffusion in Osmotically Driven Membrane Processes," Environmental Science \& Technology, vol. 43, no. 17, pp. 6769-6775, 2009/09/01 2009, doi: 10.1021/es901132x.

[21] K. S. Bowden, A. Achilli, and A. E. Childress, "Organic ionic salt draw solutions for osmotic membrane bioreactors," Bioresource Technology, vol. 122, pp. 207-216, 2012/10/01/ 2012, doi: https://doi.org/10.1016/i.biortech.2012.06.026.

[22] A. Achilli, T. Y. Cath, and A. E. Childress, "Selection of inorganic-based draw solutions for forward osmosis applications," Journal of Membrane Science, vol. 364, no. 1, pp. 233-241, 2010/11/15/ 2010, doi: https://doi.org/10.1016/j.memsci.2010.08.010. 
[23] G. K. Pearce, "UF/MF pre-treatment to RO in seawater and wastewater reuse applications: a comparison of energy costs," Desalination, vol. 222, no. 1, pp. 66-73, 2008/03/01/2008, doi: https://doi.org/10.1016/j.desal.2007.05.029.

497

498

[24] R. S. Ayres and D. W. Westcot, "FAO IRRIGATION AND DRAINAGE PAPER," Food and Agriculture Organization of the United Nations, 1985.

499 